\title{
Una exposición sobre cartografía recuerda el valor del mapa como objeto cultural
}

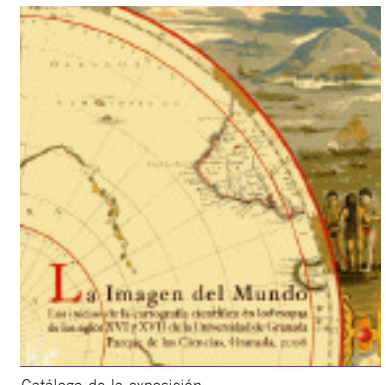

Catálogo de la exposición

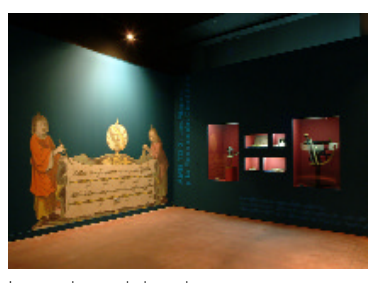

Imagen de una de las salas
El Parque de las Ciencias de Granada ofrece, desde el 17 de enero hasta finales del mes de mayo, un recorrido por la cartografía científica de los siglos XVI y XVII a través de Los inicios de la Cartografía Científica: La imagen del mundo y los mapas de los siglos XVI y XVII de la Universidad de Granada, una muestra producida por la propia Universidad de Granada en la que colabora el Observatorio de la Armada de San Fernando. La exposición presenta algunos de los aspectos culturales que han marcado la cartografía europea en los siglos XVI y XVII para poner de relieve el papel de la sociedad y la cultura en la producción de sus mapas. Todo ello en el momento en el que se desarrolla el importante proceso histórico de la Revolución Científica, impulsora, también, de los conocimientos y técnicas que harán de la cartografía una importante herramienta al servicio de los intereses de nuestra sociedad.

Los libros e imágenes que componen esta exposición pertenecen al Fondo Antiguo de la Biblioteca de la Universidad de Granada, que atesora una escogida y muy representativa colección de cartografía impresa de la Europa de los siglos XVI y XVII, parte de la cual ha querido mostrar al público con motivo del 475 aniversario de la fundación de la misma.

La investigación que conforma el tronco conceptual de la exposición se desarrolló inicialmente entre los años 1991-1993 en el marco del Centro de Investigaciones Etnológicas "Ángel Ganivet" de Granada y fue llevada a cabo por José Jesús García Rodolfo, Jaime F. López Gómez y Eugenio Cifuentes Vélez, durante la cual se estudiaron individualmente en torno a 1.200 mapas y planos de los siglos XVI y XVII del Fondo Antiguo de la Universidad, que fueron analizados desde la perspectiva del mapa como objeto cultural, que a la vez es también un productor y transmisor de imágenes sociales.

\section{Ámbitos de la exposición}

> La tradición occidental: la Antigüedad y el Medievo. Durante la Antigüedad Clásica aparecieron algunos elementos claves en la representación cartográfica que luego permanecerán, con alteraciones, en la cartografía científica como son la esfericidad de la tierra y el uso de la geometría y la matemática en la elaboración de los mapas. La Edad Media aporta la producción de mapas sagrados (los mapas del mundo "T" en "O") y los utilitarios portulanos de los navegantes.

$>$ Los mapas y la Revolución Científica. El desarrollo de la cartografía en los siglos XVI y XVII se enmarca en la denominada Revolución Científica, que podemos fechar entre 1440 y 1690. Es un largo periodo de cambios políticos, religiosos e intelectuales que, en palabras de John D. Bernal, suponen una trans- formación muy complicada donde los cambios en la técnica impulsaban a la ciencia y la ciencia, a su vez, conducía a nuevos y más rápidos cambios técnicos. Esta revolución general, técnica, económica y científica es un fenómeno social único.

$>$ Una nueva cartografía para la nueva Europa. Los avances en las técnicas de representación cartográfica durante el siglo XVI permiten definir los contornos del continente europeo, la ubicación de sus ciudades y otros elementos geográficos. Esto ayudará a conformar una imagen de Europa como continente, pero sobre todo como entidad cultural. La cartografía se convierte paulatinamente en una herramienta de descubrimientos, no sólo de nuevos continentes, sino también de viejos territorios como los asiáticos y la propia Europa. Aumenta increíblemente el número de cartógrafos y de mapas, a la vez que sorprende el anhelo por ubicar en los mapas tantas cuantas ciudades sea posible sobre un territorio.

> La imagen del mundo. El uso de imágenes, escenas y figuras es una característica consustancial a la cartografía hasta bien avanzada su historia, que irá desapareciendo con la codificación del mapa, es decir, cuando el mapa se convierte en una herramienta que se construye con signos estandarizados y de carácter más abstracto. En la época que nos ocupa, los siglos XVI y XVII, estas imágenes y figuras, la iconografia, no sólo cumplen una función decorativa sino que ponen de relieve informaciones sobre los territorios que, en muchas ocasiones, es muy superior a la propia información topográfica, siendo además fácilmente comprensible por un público más amplio.

La exposición se completa con la edición de un catálogo que pretende reflejar el eje central de esta exposición, es decir, la aparición de la cartografía científica y su significado para la sociedad de la época. En esta publicación se incluyen todos los textos e imágenes de la exposición.

La proyección de vídeos sobre algunos ámbitos de la exposición, la organización de talleres didácticos en los que los más pequeños aprenden la importancia de la cartografía a través de la elaboración de sus propios mapas y la celebración de un ciclo de conferencias impartidas por expertos en la materia son otras de las actividades que completan esta exposición que abre una ventana a la imagen del mundo hace 400 años.

Eugenio Cifuentes Vélez

Jaime F. López Gómez

Genius Loci

Responsables del concepto y los contenidos de la exposición 